\title{
Crecimiento y especialización regional del sector pecuario en México, 1994 a 2013
}

\section{Regional specialization and growth of the livestock sector in Mexico, 1994-2013}

\author{
Alfredo Rebollar Rebollara, Samuel Rebollar Rebollara, Germán Gómez Tenorioa, \\ Juvencio Hernández Martínezb, Felipe de Jesús González Razoa
}

\begin{abstract}
RESUMEN
Las políticas macroeconómicas adoptadas por México, ocasionaron una modificación en la estructura productiva del sector pecuario nacional y local. El objetivo del estudio fue determinar el crecimiento de las actividades pecuarias y la especialización regional en ocho regiones de México (Noroeste NO, Norte NR, Noreste NE, Centro-Occidente CO, Centro-Este CE, Sur SU, Oriente OR y Península de Yucatán PE) y evaluar su dinámica económica de 1994 a 2013. Se utilizaron técnicas de análisis regional, como el cociente de localización y el método diferencial-estructural modificado. Los resultados indicaron que en 1994 y 2013, las regiones NO, NE, SU y OR se especializaron en carne de bovino, y esta última, conjuntamente con CE también en pollo. La región NR se especializó en leche; en tanto que en NO, CO y PE fue en carne de cerdo. Las regiones NE, CO y CE también se especializaron en huevo de ave. De 1994 a 2003, las regiones NR, SU, CE y NO fueron dinámicas, ya que el crecimiento del sector pecuario regional $(19.94,11.59,7.04$ y $6.59 \%$ ), fue superior al nacional (4.08\%); el resto de las regiones se rezagaron. De 2003 a 2013 , la dinámica regional del sector pecuario cambió. Las regiones CO, OR y PE rezagadas en el periodo anterior, fueron dinámicas en este periodo y, las que fueron dinámicas (NO, NR, CE y SU), se rezagaron. La región NE permaneció rezagada durante los dos periodos. Se concluye que el sector pecuario mostró una dinámica y especialización distinta entre las regiones de México.
\end{abstract}

PALABRAS CLAVE: Dinámica regional, Método diferencial-estructural, Sector pecuario.

\begin{abstract}
Macroeconomic policies adopted by Mexico caused modifications in the productive structure of national and local livestock sector. The aim of the research was to determine the growth of livestock activities and regional specialization in eight regions of Mexico (Northwest NW, North NR, Northeast NE, Central West CW, Central East CE, South SU, East E and Yucatán Península PE) and assess its economic dynamics from 1994 to 2013. Regional analysis techniques such as location quotient and modified differential-structural method were used. The results indicated that in 1994, 2003 and 2013, the regions NW, NE, CE, SU and E specialized in beef, and the last region in conjunction with CE in chicken also. NR region specialized in milk; and NW, CW and PE regions was pork. NE, CW and CE regions also specialized in chicken egg. From 1994 to 2003, the NR, SO, CE and NW regions were dynamics, because the growth of the regional livestock sector $(19.94,11.59,7.04$ and $6.59 \%)$ was higher than the national growth $(4.08 \%)$; the rest of the lagged behind regions. From 2003 to 2013, the regional livestock sector dynamics changed. The CW, EA and PE lagging regions in the previous period, became dynamic in this period and which were dynamic (NW, NR, CE and SO), they behaved behind. The NE region remained behind during the two periods. It concludes that the livestock sector showed a different dynamics and specialization between regions in Mexico.
\end{abstract}

KEY WORDS: Regional dynamics, Differential-structural method, Livestock sector.

En los últimos 15 años, el sector agropecuario mexicano mostró una evolución que se
In the last $15 \mathrm{yr}$, the Mexican agricultural sector showed an evolution that was characterized by

Recibido el 10 de julio de 2015. Aceptado el 15 de octubre de 2015.

a Centro Universitario UAEM Temascaltepec. Universidad Autónoma del Estado de México. Barrio de Santiago s/n, Temascaltepec, Estado de México. 51300. México. gomte61@yahoo.com. Correspondencia al tercer autor.

b Centro Universitario UAEM Texcoco. Universidad Autónoma del Estado de México. 
caracterizó por un ritmo de crecimiento menor y una volatilidad que puso en riesgo la producción(1). Dentro de las actividades del sector, la ganadería presentó un dinamismo mayor que la agrícola, pues en diversos periodos (1995 a 2000, 2001 a 2006 y 2007 a 2010) mantuvo tasas de crecimiento medias anuales de $4.60,3.58$ y $3.42 \%$, mientras que la agricultura creció $0.55,2.82$ y $0.78 \%(2)$.

Durante 2001 a 2010, el ingreso real de la producción pecuaria en México, creció $23.66 \%$, del cual, el huevo y carne de ave registraron los incrementos mayores (38.29, $35.72 \%)$, seguidos de la carne de bovino, leche y porcino $(19.52,15.82,10.79 \%)$, crecimientos que se explicaron por aumentos en la producción y precio de los mismos(3). En ese periodo, la avicultura presentó el dinamismo mayor, debido al crecimiento registrado en Jalisco, Veracruz, Durango, Querétaro y Puebla; donde se posicionaron compañías avícolas cuya estrategia se basó en la absorción de empresas pequeñas. El ganado bovino y porcino fueron menos dinámicos, ya que el crecimiento de estas especies en las regiones noroeste, occidente y sur, fue lento(4). El cambio en la estructura productiva regional del sector pecuario en México, ha mostrado notables diferencias a través del tiempo, debido al crecimiento desigual de sus actividades.

Algunos trabajos $(5,6,7)$ han abordado temas relacionados con especialización y crecimiento regional de actividades pecuarias en México; sin embargo, estos han sido escasos, y solo se han orientado a analizar el sector porcícola.

Por ello, un análisis de dinámica de la producción pecuaria a nivel producto y región es necesario, el cual, permitiría ilustrar cambios y tendencias del sector a nivel regional. Todo ello, como indicadores que orienten a planificadores 0 diseñadores de programas de desarrollo regional, y puedan utilizarlos como herramientas que les permitirían formular políticas económicas que incentiven al sector pecuario con un enfoque territorial. Por lo anterior, el objetivo del estudio a lower growth rate and a volatility that threatened production(1). Among the activities of the sector, livestock had a greater dynamism than agricultural, because in different periods (1995-2000, 2001-2006 and 2007-2010) it maintained rates of annual average growth of 4.60, 3.58 and $3.42 \%$, while agriculture grew at $0.55,2.82$ and $0.78 \%(2)$.

During 2001-2010, real income of livestock production in Mexico, grew $23.66 \%$, of which, egg and poultry recorded the largest increase (38.29, $35.72 \%)$, followed by beef, milk and swine $(19.52,15.82,10.79 \%)$, growths that were explained by increases in production and prices thereof(3). During this period, the poultry industry had the highest dynamism, due to growth in Jalisco, Veracruz, Durango, Queretaro and Puebla; where poultry companies whose strategy was based on the absorption of small businesses are positioned. The cattle and pigs were less dynamic, since the growth of these species in the northwest regions, west and south, was slow(4). The change in the regional production structure of the livestock sector in Mexico, has shown marked differences over time, due to the uneven growth of its activities.

Some studies $(5,6,7)$ have addressed issues related to specialization and regional growth of livestock activities in Mexico; however, these have been rare, and have only been aimed at analyzing the pork sector.

Therefore, an analysis of dynamics of livestock production to product and regional level is necessary, which would allow illustrate changes and trends at the regional level. All this, as indicators to guide planners and designers of regional development programs, and can be used by them as tools that will allow to formulate economic policies that incentivize the livestock sector with more of a territorial focus. Therefore, the aim of the study was to determine the growth of livestock activities and the regional specialization in eight regions of Mexico and assess their economic dynamics from 1994 to 2013. The hypothesis was that regional 
fue determinar el crecimiento de las actividades pecuarias y la especialización regional en ocho regiones de México y evaluar su dinámica económica de 1994 a 2013. La hipótesis fue que la especialización regional contribuye a explicar el crecimiento del sector pecuario en el ámbito territorial.

Para realizar el análisis económico regional, México se dividió en ocho regiones; Noroeste NO (Baja California, Baja California Sur, Sonora, Sinaloa y Nayarit); Norte NR (Chihuahua, Coahuila, Durango San Luis Potosí y Zacatecas); Noreste NE (Nuevo León y Tamaulipas); CentroOccidente CO (Aguascalientes, Colima, Guanajuato, Jalisco y Michoacán); Centro-Este CE (Distrito Federal, Hidalgo, Estado de México, Morelos, Puebla, Querétaro y Tlaxcala); Sur SU (Chiapas, Guerrero y Oaxaca); Oriente OR (Tabasco y Veracruz) y Península de Yucatán PE (Campeche, Quintana Roo y Yucatán)(8).

Se analizó el comportamiento del valor de la producción real de las actividades del sector pecuario como carne de bovino, carne de porcino, carne de pollo, leche de bovino y huevo de ave, a nivel regional y nacional, durante los periodos 1994 a 2003 y 2003 a 2013.

El primer periodo incluyó el inicio del Tratado del Libre Comercio con América del Norte (TLCAN) y, finalizó con la desgravación para productos pecuarios (excepto la leche en polvo); mientras que el segundo, comprendió la eliminación arancelaria total para productos agropecuarios $(9)$ y, finalizó con la evolución del sector hasta tiempos más recientes.

Se utilizaron dos técnicas de análisis regional (TAR): el cociente de localización(10) y el método "shift and share" con modificación de estructuras (conocido como método diferencial-estructural modificado)(11); ambas herramientas dentro de la etapa de diagnóstico e investigación utilizadas en manuales de la CEPAL (Comisión Económica para América Latina), que permiten medir y caracterizar a una región mediante la descripción de unidades básicas de producción(10). specialization helps explain the growth of the livestock sector in the territory.

To carry out the regional economic analysis, Mexico was divided into eight regions; Northwest, NW (Baja California, Baja California Sur, Sonora, Sinaloa and Nayarit); North, NR (Chihuahua, Coahuila, Durango, San Luis Potosi and Zacatecas); Northeast, NE (Nuevo Leon and Tamaulipas); Central-West, CW (Aguascalientes, Colima, Guanajuato, Jalisco and Michoacan); Central-East, CE (Federal District, Hidalgo, State of Mexico, Morelos, Puebla, Queretaro and Tlaxcala); South, SU (Chiapas, Guerrero and Oaxaca); East EA (Tabasco and Veracruz); and Yucatan Peninsula, PE (Campeche, Yucatan and Quintana Roo)(8).

The behavior of the value of the actual production in the activities of the livestock sector at the regional and national level during the periods 1994-2003 and 2003-2013 was analyzed for pork, chicken, milk, beef and chicken eggs.

The first period included the start of Free Trade Agreement with North America (NAFTA) and ended with removal of tariffs for livestock products (except milk powder); while the second period, involved full tariff elimination for agricultural products $(9)$ and ended with the evolution of the sector to more recent times.

Two regional analysis techniques (ART) were used: location quotient(10) and the "shift and share" method with modification of structures (known as a modified differential-structural method)(11). Both tools are part of research and diagnostic manuals used in ECLAC (Economic Commission for Latin America) in order to measure and characterize a region by describing basic production units(10).

The indicators were calculated by developing three types of sector-region matrices (SECRE)(10) that consisted of a double entry table, where rows represent the activities of the livestock sector and the columns the regions studied. The information processing was performed with the TASK v3.0 software(12) and 
Los indicadores, se calcularon a partir de la elaboración de tres matrices tipo sector-región $(\mathrm{SECRE})(10)$, que consisten en una tabla de doble entrada, donde las filas representaron las actividades del sector pecuario y las columnas las regiones que se estudiaron. El procesamiento de la información se realizó con el software TAREA v3.0(12) y Microsoft Excel 2011. La variable de análisis que se utilizó, fue el valor de la producción regional a precios constantes (Base 2012= 100) para cada uno de los productos pecuarios. Los valores corrientes por entidad federativa, se obtuvieron del Sistema de Información Agroalimentaria y Pesquera (SIAP)(13).

El cociente de localización (Qij), indica el tamaño relativo de una actividad en una región, comparado con el tamaño relativo de la misma actividad a nivel nacional. La expresión de Qij es la siguiente:

$\mathrm{Q}_{\mathrm{ij}}=\frac{\mathrm{V}_{\mathrm{ij}}}{\Sigma_{\mathrm{i}} \mathrm{V}_{\mathrm{ij}}} / \frac{\Sigma_{\mathrm{j}} \mathrm{V}_{\mathrm{ij}}}{\Sigma_{\mathrm{i}} \Sigma_{\mathrm{j}} \mathrm{V}_{\mathrm{ij}}}$

Donde $\mathrm{V}_{\mathrm{ij}}=$ valor de la variable $\mathrm{V}$ correspondiente a la actividad "i" y la región "j"; $\Sigma_{\mathrm{i}} \mathrm{V}_{\mathrm{ij}}=$ valor de la variable $\mathrm{V}$ correspondiente al total regional; $\Sigma_{\mathrm{j}} \mathrm{V}_{\mathrm{ij}}=$ valor de la variable $\mathrm{V}$ correspondiente al total nacional de la actividad "i"; $\quad \Sigma_{\mathrm{i}} \Sigma_{\mathrm{j}} \mathrm{V}_{\mathrm{ij}}=$ valor de la variable $\mathrm{V}$ correspondiente al total nacional.

Los valores que adopta $\mathrm{Q}_{\mathrm{ij}}$ son: $\mathrm{Q}_{\mathrm{ij}}=1$, indica que si el tamaño relativo de la actividad "i" en la región "j", es idéntico al tamaño relativo de la misma actividad en el país, no hay especialización regional en la actividad "i". $\mathrm{Q}_{\mathrm{ij}}<1$, indica que si el tamaño relativo de la actividad "i" en la región "j", es menor al tamaño relativo de la misma actividad en el país, no hay especialización regional en la actividad "i". $\mathrm{Q}_{\mathrm{ij}}>1$, indica que si el tamaño relativo de la actividad "i" en la región "j", es mayor al tamaño relativo de la misma actividad en el país, se trata de una especialización regional en la actividad "i".

El método diferencial-estructural modificado, consiste en comparar el cambio observado en
Microsoft Excel 2011. The variable analysis used was the value of regional output at constant prices (Base 2012=100) for each of the livestock products. The current values by State were obtained from the Agricultural Information System and Fisheries (SIAP)(13).

The location quotient $\left(Q_{i j}\right)$, indicates the relative size of an activity in a region, compared to the relative size of the same activity at the national level. $\mathrm{Q}_{\mathrm{ij}}$ expression is:

$\mathrm{Q}_{\mathrm{ij}}=\frac{\mathrm{V}_{\mathrm{ij}}}{\Sigma_{\mathrm{i}} \mathrm{V}_{\mathrm{ij}}} / \frac{\Sigma_{\mathrm{j}} \mathrm{V}_{\mathrm{ij}}}{\Sigma_{\mathrm{i}} \Sigma_{\mathrm{j}} \mathrm{V}_{\mathrm{ij}}}$

Where $\mathrm{V}_{\mathrm{ij}}=$ value of the variable $\mathrm{V}$ corresponding to the activity "i" and the region " $\mathrm{j}$ "; $\Sigma_{\mathrm{i}} \mathrm{V}_{\mathrm{ij}}=$ value of the variable $V$ for the regional total; $\Sigma_{j}$ $\mathrm{V}_{\mathrm{ij}}=$ value of the variable $\mathrm{V}$ corresponding to the national total activity "i"; $\Sigma_{\mathrm{i}} \Sigma_{\mathrm{j}} \mathrm{V}_{\mathrm{ij}}=$ value of the variable $V$ corresponding to the national total.

The values assumed for $Q_{i j}$ are: $Q_{i j}=1$, indicates that if relative size of the activity " $i$ " in the region " $j$ " is identical to the relative size of the same activity in the country, then there is no regional specialization in the activity "i". $Q_{i j}<1$ indicates that if the relative size of the activity " $i$ " in the region " $j$ " is less than the relative size of the same activity in the country, no regional specialization in the activity " $i$ ". $Q_{i j}>1$, indicates that if the relative size of the activity " $i$ " in the region " $j$ " is greater than the relative size of the same activity in the country, there is a regional specialization in the activity " $i$ ".

The differential-structural modified method is used to compare the observed change in a variable that has occurred over a period of time, both in a region and in a country $(10)$. This method was used to determine whether the regional specialization evolved into sectors that are more dynamic or to see if the structural change was characterized by a specialization in sectors in decline at the end of the study.

The "shift and share" structural modification methodology, is broken down into four 
una variable ocurrido en un periodo de tiempo, tanto en la región, como en el país(10). Este método, se utilizó para indicar si la especialización regional evolucionó hacia sectores con mayor dinamismo o, el cambio estructural se caracterizó por una especialización en sectores en retroceso al final del estudio.

El método shift and share con modificación de estructuras, se desagrega en cuatro componentes: efecto total (ET), efecto regional modificado (ERM), efecto estructural (EE) y efecto estructural modificado (EEM).

El ET, compara el valor final de la variable en estudio en la región $j$, con el valor que hipotéticamente habría tenido dicha variable si la región se hubiera comportado como el país, en términos de crecimiento. La expresión del ET es:

$\mathrm{ET}_{\mathrm{j}}=\sum_{\mathrm{i}=1}^{\mathrm{n}} \mathrm{V}_{\mathrm{ij}}(\mathrm{t})-\left[\sum_{\mathrm{i}=1}^{\mathrm{n}} \mathrm{V}_{\mathrm{ij}}(0) * \mathrm{rSR}\right]$

Donde $V_{i j}=$ valor de la variable $V$ correspondiente a la actividad "i", en la región "j".

$0=$ año inicial; $t=$ año final; $r S R=$ coeficiente de variación a nivel nacional; $r S R=$ $\frac{\sum_{\mathrm{i}} \sum_{\mathrm{j}} \mathrm{V}_{\mathrm{ij}}(t)}{\sum_{\mathrm{i}} \sum_{\mathrm{j}} \mathrm{V}_{\mathrm{ij}}(0)}$.

Un ET positivo indica "ganancia hipotética" debido al crecimiento mayor del sector pecuario en la región, comparado con el nacional. Un ET negativo indica "pérdida hipotética", dado que el crecimiento del sector en la región fue menor que en el país(10). El ET se explica por la combinación del efecto regional modificado (ERM), efecto estructural (EE) y efecto estructural modificado (EEM).

$$
E T_{j}=E R M_{j}+E E_{j}+E E M_{j}
$$

El efecto estructural, refleja la diferencia en la composición de actividades entre la región y el components: the total effect (TE), as amended regional effect (ARE), structural effect (SE) and modified structural effect (MSE).

TE compares the final value of the variable under study in region $j$, the value that hypothetically would have had this variable if the region had behaved like the country, in terms of growth. The expression of TE is:

$$
\mathrm{TE}_{\mathrm{j}}=\sum_{\mathrm{i}=1}^{\mathrm{n}} \mathrm{V}_{\mathrm{ij}}(\mathrm{t})-\left[\sum_{\mathrm{i}=1}^{\mathrm{n}} \mathrm{V}_{\mathrm{ij}}(0) * \mathrm{rSR}\right]
$$

Where $\mathrm{V}_{\mathrm{ij}}=$ value of the variable $\mathrm{V}$ corresponding to the activity "i" in the region " $j "$.

$0=$ initial year; $t=$ final year; $r S R=$ coefficient of variation at national level where $\mathrm{rSR}=$ $\frac{\sum_{\mathrm{i}} \sum_{\mathrm{j}} \mathrm{V}_{\mathrm{ij}}(t)}{\sum_{\mathrm{i}} \sum_{\mathrm{j}} \mathrm{V}_{\mathrm{ij}}(0)}$.

A positive TE indicates "hypothetical gain" due to the increased growth of the livestock sector in the region, compared to the national. A negative TE indicates "hypothetical loss", as the sector's growth in the region was lower than in the country $(10)$. TE is given by the combination of the modified regional effect (ARE), structural effect (EE) and modified structural effect (MSE).

$$
\mathrm{TE}_{\mathrm{j}}=A R E_{j}+\mathrm{SE}_{\mathrm{j}}+\mathrm{MSE}_{\mathrm{j}}
$$

The structural effect reflects the difference in the composition of activities between the region and the country, derived from a different production structure at beginning of period(10). The SE expression is:

$E E_{j}=\sum_{i=1}^{n}\left\{r S_{i} *\left[\frac{\mathrm{V}_{\mathrm{ij}}(0)}{\sum_{\mathrm{i}} \mathrm{V}_{\mathrm{ij}}(0)}-\frac{\sum_{\mathrm{j}} \mathrm{V}_{\mathrm{ij}}(0)}{\sum_{\mathrm{i}} \sum_{\mathrm{j}} \mathrm{V}_{\mathrm{ij}}(0)}\right]\right\} * \sum_{\mathrm{i}=1}^{\mathrm{n}} \mathrm{V}_{\mathrm{ij}}(0)$

Where national $\mathrm{rSi}=$ coefficient of variation activity $r S i=\frac{\sum j V_{i j}(t)}{\sum j V_{i j}(0)}$. 
país, derivada de una estructura productiva distinta al inicio del periodo(10). La expresión del EE es:

$$
E E_{j}=\sum_{i=1}^{n}\left\{r S_{i} *\left[\frac{\mathrm{V}_{\mathrm{ij}}(0)}{\sum_{\mathrm{i}} \mathrm{V}_{\mathrm{ij}}(0)}-\frac{\sum_{\mathrm{j}} \mathrm{V}_{\mathrm{ij}}(0)}{\sum_{\mathrm{i}} \sum_{\mathrm{j}} \mathrm{V}_{\mathrm{ij}}(0)}\right]\right\} * \sum_{\mathrm{i}=1}^{\mathrm{n}} \mathrm{V}_{\mathrm{ij}}(0)
$$

Donde $\mathrm{rSi}=$ coeficiente de variación nacional por actividad $r S i=\frac{\sum j V_{i j}(t)}{\sum j V_{i j}(0)}$

Un EE positivo indica especialización regional al inicio del periodo en actividades dinámicas en el país; mientras que un EE negativo refiere especialización regional en actividades en retroceso en el ámbito nacional.

El efecto estructural modificado indica el cambio de la diferencia existente en la estructura productiva regional al inicio y final del periodo de estudio. Se obtiene a través de la diferencia del efecto estructural inverso (EI) y EE.

$$
E E M_{j}=E I_{j}-E E_{j}
$$

Donde: $E I_{j}=\sum_{i=1}^{n}\left\{V_{i j}(\mathrm{t}) *\left[\frac{\sum_{\mathrm{i}} \sum_{\mathrm{j}} \mathrm{V}_{\mathrm{ij}}(0)}{\sum_{\mathrm{i}} \sum_{\mathrm{j}} \mathrm{V}_{\mathrm{ij}}(\mathrm{t})}-\frac{\sum_{\mathrm{j}} \mathrm{V}_{\mathrm{ij}}(0)}{\sum_{\mathrm{j}} \mathrm{V}_{\mathrm{ij}}(\mathrm{t})}\right]\right\}$

Un EEM positivo, indica especialización regional al final del periodo en actividades dinámicas en el país; mientras que un EEM negativo, refiere especialización regional en actividades en retroceso a nivel nacional.

El efecto regional modificado, determina la dinámica regional de cada actividad. Su expresión es:

$$
E R M_{j}=E T_{j}-E E_{j}-E E M_{j}
$$

Un ERM positivo indica que la región es ganadora; mientras que un ERM negativo refiere que la región es perdedora(12).

Durante los años de estudio, todas las regiones de México obtuvieron cocientes de localización
A positive SE indicates regional specialization at the beginning of the period in dynamic activities in the country; while a negative SE refers regional specialization in activities in decline at the national level.

The modified structural effect indicates the change in the difference in the regional production structure at the beginning and at end of the study period. It is obtained through the inverse difference structural effect EI and SE.

Where: $E I_{j}=\sum_{i=1}^{n}\left\{V_{i j}(\mathrm{t}) *\left[\frac{\sum_{\mathrm{i}} \sum_{\mathrm{j}} \mathrm{V}_{\mathrm{ij}}(0)}{\sum_{\mathrm{i}} \sum_{\mathrm{j}} \mathrm{V}_{\mathrm{ij}}(\mathrm{t})}-\frac{\sum_{\mathrm{j}} \mathrm{V}_{\mathrm{ij}}(0)}{\sum_{\mathrm{j}} \mathrm{V}_{\mathrm{ij}}(\mathrm{t})}\right]\right\}$

A positive MSE, indicates regional specialization at the end of the period of dynamic activity in the country; while a negative MSE, refers regional specialization in activities in decline nationally.

The modified regional effect, determines the regional dynamics of each activity. This expression is:

$$
A R E_{j}=T E_{j}-S E_{j}-M S E_{j}
$$

A positive ARE indicates that the region is winning; while a negative ARE indicates that the region is losing(12).

During the years of study, all regions of Mexico obtained positive ratios, below and above the unit value, distributed in different livestock activities. These values indicate the presence or absence of regional specialization since the relative size of the value of the actual production that generated those products in the regions was more or less the same as products at the national level(14).

During 1994, the CW, PE, NW and SU regions specialized in pork and poultry eggs (except SU for egg); the latter two regions, did the same 
Cuadro 1. Cocientes de localización del valor de la producción real por región de las actividades pecuarias en México: 1994

Table1. Location coefficients of actual cost of production by region of livestock activities in Mexico: 1994

\begin{tabular}{lcccccccc}
\hline Activity & NW & NR & NE & CW & CE & SU & EA & PE \\
\hline Beef & 1.27 & 1.02 & 1.78 & 0.76 & 0.48 & 1.55 & 1.59 & 0.80 \\
Chicken meat & 0.38 & 0.75 & 0.76 & 0.83 & 1.82 & 0.54 & 1.18 & 1.60 \\
Bovine milk & 0.46 & 1.95 & 0.17 & 1.15 & 0.95 & 0.77 & 0.85 & 0.10 \\
Pork meat & 1.76 & 0.26 & 0.66 & 1.23 & 0.84 & 1.29 & 0.48 & 1.84 \\
Chicken egg & 1.26 & 0.57 & 1.37 & 1.32 & 1.40 & 0.29 & 0.12 & 1.07 \\
\hline
\end{tabular}

Regions of Mexico: Northwest (NW); North (NR); Northeast (NE); Center-West (CW); East Central (CE); South (SU); East (EA) and Yucatan Peninsula (PE).

positivos, inferiores y superiores a la unidad, distribuidos en las distintas actividades pecuarias; estos valores indicaron presencia o ausencia de especialización regional dado que el tamaño relativo del valor de la producción real que generaron esos productos en las regiones, fue mayor o menor a los mismos productos en el ámbito nacional(14).

Durante 1994, las regiones CO, PE, NO y SU se especializaron en carne de porcino y huevo de ave (excepto SU en huevo); estas dos últimas regiones, también lo hicieron en carne de bovino, conjuntamente con NR, NE y OR. La región NR también lo hizo en leche, mientras que NE y CE lo hicieron en huevo y, CE también en pollo (Cuadro 1). En 2013, las regiones NO, CO y OR continuaron su especialización en las mismas actividades que el año anterior, mientras que el resto de las regiones cambiaron su especialización hacia otros productos. La región NR incrementó su especialización en leche; mientras que la región NE continuó especializándose en carne de bovino y huevo. La región CE continuó en pollo y huevo y, añadió, leche y carne de porcino. La región SU continuó su especialización en carne de bovino, disminuyó en porcino y adicionó pollo. La región PE incrementó su especialización en carne de cerdo y continuó en carne de pollo (Cuadro 2).

Durante el estudio, en algunas regiones hubo tendencia a especializarse en ciertas actividades for beef, together with NR, NE and EA. The NR region also did it in milk, while NE and CE did so with egg and only CE with chicken (Table 1). In 2013, the regions NW, CW and EA continued their specialization in the same activities as the previous year, while the rest of the regions changed their expertise to other products. The NR region increased its specialization in milk; while the NE region continued specializing in beef and egg. The CE region continued in chicken and egg and added, milk and pork. The SU region continued to specialize in beef, pork decreased and they added chicken. The $P E$ region increased its specialization in pork and continued with chicken meat (Table 2).

During the study, in some regions there was a tendency to specialize in certain livestock activities, such as regions NW, NE, SU and EA in beef meat. The productive vocation of the first two can be partly explained by their cowcalf grazing system of production and their feedlot for fattening with high technological levels partly explained. While regions SU and EA are productive areas with dual-purposes and providing areas for fattening calves and finishing feedlots, where their destinations are the markets of central Mexico(15).

In comparison, the regions $\mathrm{CE}$ and $\mathrm{EA}$ remained specializing in chicken meat. Its production profile is positioned as such due to the high 
Cuadro 2. Cocientes de localización del valor de la producción real por región de las actividades pecuarias en México: 2013

Table 2. Location ratios of actual cost of production by region for livestock activities in Mexico: 2013

\begin{tabular}{lllllllll}
\hline Activity & NW & NR & NE & CW & CE & SU & EA & PE \\
\hline Beef & 1.64 & 1.02 & 1.54 & 0.63 & 0.59 & 1.68 & 1.68 & 0.69 \\
Chicken meat & 0.61 & 0.98 & 0.93 & 0.87 & 1.29 & 1.05 & 1.22 & 1.29 \\
Bovine milk & 0.40 & 2.18 & 0.21 & 0.94 & 1.04 & 0.86 & 0.66 & 0.09 \\
Pork meat & 1.62 & 0.18 & 0.89 & 1.05 & 1.02 & 0.92 & 0.96 & 2.33 \\
Chicken egg & 0.88 & 0.33 & 1.38 & 1.80 & 1.06 & 0.16 & 0.07 & 0.86 \\
\hline
\end{tabular}

Regions of Mexico: Northwest (NW); North (NR); Northeast (NE); Center-West (CW); Central East (CE); South (SU); East (EA) and Yucatan Peninsula (PE).

pecuarias, tales como las regiones $\mathrm{NO}, \mathrm{NE}, \mathrm{SU}$ y OR en carne de bovino. La vocación productiva en las dos primeras, se explicó en parte por el sistema de producción vaca-becerro bajo pastoreo y de engorda en corral con niveles tecnológicos altos. Mientras que las regiones SU y OR son áreas productoras de doble propósito y proveedoras de becerros para engorda y finalización en corral, cuyos destinos son los mercados del centro de México(15).

Por su parte, las regiones CE y OR permanecieron especializadas en carne de pollo. Su vocación productiva obedeció al posicionamiento de compañías avícolas con grado tecnológico alto, ubicadas en Veracruz y Querétaro, cuya estrategia se basó en la absorción de empresas pequeñas(4). La permanencia de la región NR en leche de bovino, se explicó por la dinámica de la ganadería intensiva ubicada en la comarca lagunera (Coahuila y Durango), cuyas empresas se manejan con grado de tecnificación alto(16) que reflejan productividad en el uso de mano de obra y tierra y hacen que la actividad sea rentable y competitiva(17).

Las regiones NO, PE y CO permanecieron especializadas en carne de porcino. La vocación de las dos primeras se explicó por la dinámica de la porcicultura en Sonora y Yucatán(5), que se basó en la implementación de nuevas formas de comercialización, dinámica exportadora y technological level of poultry companies located in Veracruz and Queretaro, whose strategy has been based on the absorption of small businesses( 4 ). The permanence of the NR region in bovine milk was explained by the dynamics of intensive cattle farming located in the Laguna region (Coahuila and Durango), where companies use a high degree of mechanization(16) which is reflected in its productivity in the use of labor and land and make the activity profitable and competitive(17).

The NW, PE and CW regions remained specialized in pig meat. The vocation of the first two, can be explained by the dynamics of pork production in Sonora and Yucatan(5), which was based on the implementation of new forms of marketing, export dynamics and advanced technologies $(6,18)$. In the $\mathrm{CW}$ region, the pig remained an activity of slow growth(5), because of lack of supportive policies and inefficient use of resources(7), with a low level of productivity(19) and low degree of mechanization compared to companies positioned in Jalisco(20); this led to classification of the region as a laggard region(5).

Some regions such as CW, CE and NE also specialized in poultry eggs, its productive vocation explained by the dynamics of Jalisco, Puebla and Nuevo Leon; entities with hightechnology companies that were able to increase their efficiency and productivity of their production systems(21). 
tecnologías avanzadas $(6,18)$. En la región $\mathrm{CO}$, la porcicultura permaneció como una actividad de crecimiento lento(5), a causa de falta de políticas de apoyo e ineficiencia en el uso de los recursos(7), nivel de productividad bajo(19) y grado bajo de tecnificación de las empresas posicionadas en Jalisco(20); ello llevó a que se le clasificara como una región rezagada(5).

Algunas regiones como $\mathrm{CO}, \mathrm{CE}$ y NE también se especializaron en huevo de ave, su vocación productiva se explicó por la dinámica de Jalisco, Puebla y Nuevo León; entidades donde se asentaron empresas con grado tecnológico alto que lograron incrementar la eficiencia y productividad de los sistemas de producción(21).

Si bien el cociente de localización genera información sobre presencia o ausencia de especialización regional, hay causas que afectan su magnitud, como la distribución del ingreso, hábitos de consumo, tecnología y eficiencia en el uso de los recursos. Su alcance depende del nivel de desagregación de la información(10).
Although the location quotient generates information about presence or absence of regional specialization, there are causes that affect its magnitude, such as income distribution, consumption habits, technology and efficient use of resources. Its scope depends on the level of disaggregation of information(10).

In the period 1994 to 2003, NR, CE, SU and NW regions had a positive overall effect (TE) due to higher growth in the value of real output recorded by the livestock sector in the regions, compared with growth in the country; therefore, these regions were considered as dynamic (Table 3).

TE values in regions NR and SU had greater impact, due to the role that the modified regional effect (ARE) and modified structural effect (MSE), which were also positive. ARE values indicated that chicken meat and bovine milk recorded higher growth in the regions, than in the country. MSE values meant that regions modified their production structure at the end of the period and reoriented their specialization towards dynamic activities at the national level such as with milk and chicken

Cuadro 3. Coeficientes obtenidos de la aplicación del método diferencial-estructural modificado al valor de la producción pecuaria real por región en México: 1994-2003 (millones de pesos)

Table 3. Coefficients obtained from the application of the modified differential-structural method to the actual cost of production by region of livestock activities in Mexico: 1994-2003 (millions of Mexican pesos)

\begin{tabular}{lrrcc}
\hline & \multicolumn{4}{c}{ Effects } \\
\cline { 2 - 5 } Region & \multicolumn{1}{c}{ Total } & Structural & Modified structural & Modified regional \\
\hline NW & 539.35 & $-1,077.11$ & -79.29 & $1,695.76$ \\
NR & $4,427.86$ & -200.92 & 318.61 & $4,310.17$ \\
NE & -590.13 & -462.98 & 265.74 & -392.89 \\
CW & $-1,990.24$ & 427.32 & 507.73 & $-2,925.29$ \\
CE & $1,018.99$ & $2,496.59$ & -462.95 & $-1,014.65$ \\
SU & 948.95 & -781.61 & 65.75 & $1,664.81$ \\
EA & $-2,802.05$ & -690.41 & -235.16 & $-1,876.48$ \\
PE & $-1,552.73$ & 289.13 & -380.42 & $-1,461.44$ \\
\hline
\end{tabular}

Regions of Mexico: Northwest (NW); North (NR); Northeast (NE); Center-West (CW); Central East (CE); South (SU); East (EA) and Yucatan Peninsula (PE). 
Cuadro 4. Crecimiento del valor de la producción real por región de las actividades pecuarias en México: 1994-2003 $(\%)$

Table 4. Growth in the cost of actual production by region of livestock activities in Mexico: 1994-2003 (\%)

\begin{tabular}{|c|c|c|c|c|c|c|c|c|c|}
\hline Activity & NW & NR & $\mathrm{NE}$ & $\mathrm{CW}$ & CE & SU & EA & PE & Nationa \\
\hline Beef & -2.08 & -6.38 & -30.46 & -26.81 & -7.66 & -4.86 & -16.96 & -11.88 & -14.29 \\
\hline Chicken meat & 78.99 & 84.36 & 84.87 & 37.09 & 14.06 & 90.97 & -0.35 & -33.31 & 29.28 \\
\hline Bovine milk & 30.23 & 24.72 & 21.82 & -11.29 & 10.59 & 31.49 & -12.24 & -4.12 & 6.96 \\
\hline Pork meat & 5.52 & -12.77 & 26.39 & -3.05 & -11.92 & 1.03 & 33.20 & 8.19 & 1.13 \\
\hline Chicken egg & -21.41 & -2.81 & -14.52 & 31.16 & 17.59 & -30.38 & 1.98 & -15.26 & 11.04 \\
\hline Livestock & 6.59 & 19.94 & -3.22 & 0.57 & 7.04 & 11.59 & -8.16 & -12.57 & 4.08 \\
\hline
\end{tabular}

Regions of Mexico: Northwest (NW); North (NR); Northeast (NE); Center-West (CW); Central East (CE); South (SU); East (EA) and Yucatan Peninsula (PE).

En el periodo 1994 a 2003, las regiones NR, $\mathrm{CE}$, SU y NO tuvieron un efecto total (ET) positivo debido al crecimiento mayor del valor de la producción real registrado por el sector pecuario en las regiones, comparado con el crecimiento en el país; por ello, estas regiones se consideraron como dinámicas (Cuadro 3).

Los valores de ET en las regiones NR y SU se debieron a la aportación mayor que realizó el efecto regional modificado (ERM) y efecto estructural modificado (EEM) que también fueron positivos. Los valores del ERM indicaron que la carne de pollo y la leche de bovino registraron crecimientos superiores en las regiones, que en el país. Los valores de EEM significaron que las regiones modificaron su estructura productiva al final del periodo y reorientaron su especialización hacia actividades dinámicas en el ámbito nacional como fueron leche y carne de pollo. El valor positivo del ET en la región no fue influenciado por el valor del ERM, que significó un crecimiento mayor de carne de pollo, leche de bovino y carne de porcino en la región, comparado con el registrado en el país (Cuadro 4).

EI ET en la región CE lo determinó el valor de $E E$, éste significó que la región se especializó al inicio del periodo en actividades dinámicas en el ámbito nacional como carne de pollo y huevo. Por su parte, las regiones $\mathrm{OR}, \mathrm{CO}, \mathrm{PE}$ y $\mathrm{NE}$ tuvieron ET negativos. Estos valores indicaron meat. The positive value of TE in the NW region was not influenced by the value of ARE, which meant increased growth of poultry meat, milk, beef and pork meat in the region, compared with that recorded in the country (Table 4).

The TE in the CE region was determined by the value of $\mathrm{EE}$, this meant that the region specialized at beginning of period in dynamic activities at the national level as chicken meat and egg. Meanwhile, regions EA, CW, PE and NE had negative TE. These values indicated that the growth of real output value of the livestock sector in the regions was lower than that obtained by the country; therefore, these regions were considered as laggards, and specialization in activities in decline at the national level, such as beef and pork.

During 2003-2013, CW, EA and PE regions had positive $T E$, due to the higher growth of real output value of the livestock sector in these regions compared to registered in the country; therefore, these regions were considered dynamic (Table 5).

The magnitude and sign of TE in these regions are due to the positive contribution of all factors that generate it (except SE in the region EA). The ARE indicated that activities such as chicken, pork (except CW), beef and egg (except EA and PE) and milk (except EA and PE) obtained 


\section{CRECIMIENTO Y ESPECIALIZACIÓN REGIONAL DEL SECTOR PECUARIO EN MEXICO}

Cuadro 5. Coeficientes obtenidos de la aplicación del método diferencial-estructural modificado al valor de la producción pecuaria real por región en México: 2003-2013 (millones de pesos)

Table 5. Coefficients obtained from the application of the differential-structural method, modified to the actual cost of livestock production by region in Mexico: 2003-2013 (millions of Mexican pesos)

\begin{tabular}{lrrcc}
\hline & \multicolumn{4}{c}{ Effects } \\
\cline { 2 - 5 } Region & Total & Structural & Modified Structural & Modified Regional \\
\hline NW & $-2,600.70$ & -881.88 & 469.75 & $-2,188.56$ \\
NR & $-2,179.23$ & $-2,320.51$ & 512.12 & -370.85 \\
NE & $-2,409.47$ & 329.74 & -138.80 & $-2,600.41$ \\
CW & $11,994.62$ & $2,245.53$ & 209.48 & $9,539.61$ \\
CE & $-5,147.92$ & $2,882.28$ & $-2,250.69$ & $-5,779.50$ \\
SU & $-1,377.89$ & $-1,134.64$ & 590.87 & -834.12 \\
EA & 580.47 & $-1,227.26$ & 523.10 & $1,284.63$ \\
PE & $1,140.12$ & 106.73 & 84.17 & 949.21 \\
\hline
\end{tabular}

Regions of Mexico: Northwest (NW); North (NR); Northeast (NE); Center-West (CW); Central East $(\mathrm{CE})$; South (SU); East (EA) and Yucatan Peninsula (PE).

que el crecimiento del valor de la producción real del sector pecuario en las regiones, fue menor al obtenido por el país; en consecuencia, estas regiones se consideraron como rezagadas, y con especialización en actividades en retroceso en el ámbito nacional, como carne de bovino y porcino.

Durante 2003 a 2013, las regiones CO, OR y PE tuvieron ET positivos, debido al crecimiento mayor del valor de la producción real del sector higher growth in the regions, compared to the same activities in the country (Table 6).

Meanwhile the values of SE and MSE meant that regions (except EA) began and ended the period specializing in activities that are dynamic at the national level, such as chicken and egg. The regions NW, NR, NE, CE and SU had negative $\mathrm{TE}$, due to the lower growth of beef, pork, chicken, milk and egg, in some regions for the country, as well as a specialization at the end of period

Cuadro 6. Crecimiento del valor de la producción real por región de las actividades pecuarias en México: 2003-2013 (\%)

Table 6. Growth of real output value by region of livestock activities in Mexico: 2003-2013 (\%)

\begin{tabular}{lcccccrrrr}
\hline Activity & NW & NR & NE & CW & CE & \multicolumn{1}{c}{ SU } & \multicolumn{1}{c}{ EA } & \multicolumn{1}{c}{ PE } & National \\
\hline Beef & 47.10 & 37.50 & 8.26 & 45.38 & 45.22 & 35.03 & 34.77 & 6.45 & 37.49 \\
Chicken meat & 86.04 & 72.38 & 6.79 & 85.69 & 27.31 & 123.44 & 105.60 & 144.15 & 69.84 \\
Bovine milk & -14.63 & 34.31 & 4.19 & 38.23 & 25.52 & 15.62 & 8.13 & 8.20 & 27.15 \\
Pork meat & 13.48 & 18.39 & 7.48 & 32.80 & 76.50 & -2.70 & 86.54 & 46.92 & 35.55 \\
Egg & 87.13 & 46.37 & 95.09 & 155.29 & 34.83 & 75.88 & 19.37 & 96.13 & 101.32 \\
Livestock & 38.74 & 43.58 & 19.28 & 71.14 & 36.11 & 40.31 & 52.84 & 64.06 & 50.08 \\
\hline
\end{tabular}

Regions of Mexico: Northwest (NW); North (NR); Northeast (NE); Center-West (CW); Central East (CE); South (SU); East (EA) and Yucatan Peninsula (PE). 
pecuario en esas regiones, comparado con el registrado en el país; por ello, estas regiones se consideraron dinámicas (Cuadro 5 ).

La magnitud y signo de los ET en esas regiones, se debió a la aportación positiva que realizaron todos los efectos que lo integran (excepto EE en la región OR). Los ERM indicaron que las actividades como carne de pollo, carne de porcino (excepto CO), carne de bovino y huevo (excepto OR y PE) y leche (excepto OR y PE) obtuvieron crecimientos superiores en las regiones, comparado con las mismas actividades en el país (Cuadro 6).

Por su parte los valores de EE y EEM significaron que las regiones iniciaron (excepto OR) y finalizaron el periodo especializándose en actividades dinámicas en el ámbito nacional, como carne de pollo y huevo. Las regiones NO, NR, NE, CE y SU tuvieron ET negativos, debido al crecimiento inferior de carne de bovino, porcino, pollo, leche y huevo, en algunas regiones respecto al país, además de una especialización al final del periodo en actividades en retroceso en el ámbito nacional como carne de bovino y porcino.

Las regiones NR, SU, CE y NO que fueron dinámicas durante el periodo 1994 a 2003, se rezagaron en 2003 a 2013, debido a un cambio en el crecimiento del valor de la producción del sector pecuario en esas regiones, pues de ser superior durante el primer periodo (19.94, 11.59, 7.04 y $6.59 \%)$, cambió a inferior en el segundo periodo (43.58, 40.31, 36.11 y $38.74 \%$ ); ellos, en relación con el crecimiento del sector pecuario nacional en ambos periodos (4.08 y $50.08 \%$ ). El cambio de dinamismo del sector pecuario en esas regiones, se debió a factores regionales que ocasionaron una disminución en el crecimiento del volumen de producción de algunas actividades como carne de pollo y leche de bovino, además de la especialización regional en actividades en retroceso en el ámbito nacional, como leche, carne de bovino y porcino.

Las regiones $\mathrm{CO}, \mathrm{PE}$ y $\mathrm{OR}$ que se rezagaron en el primer periodo, pasaron a ser dinámicas durante segundo periodo, debido a que en este with activities that are shrinking at the national level such as beef and pork.

The regions NR, SU, CE and NW were dynamic during the period 1994 to 2003, lagged behind in 2003 to 2013, due to an increase of the cost of production of the livestock sector in those regions. These were better for the first period (19.94, 11.59, 7.04 and $6.59 \%)$, were inferior in the second period (43.58, 40.31, 36.11 and $38.74 \%$ ), and also inferior in relation to the growth of national livestock sector in both periods (4.08 and $50.08 \%$ ). The change of dynamism of the livestock sector in those regions is due to regional factors that caused a decrease in the growth of production volume of some activities such as poultry, meat and milk from cattle, in addition to regional specialization in activities in decline at the national level, such as milk, beef and pork.

$\mathrm{CW}, \mathrm{PE}$ and EA regions lagged behind in the first period, became dynamic during the second period, because in the latter, the regional livestock sector growth exceeded the national.

The growth of chicken, egg and pork, as well as regional specialization in the first two products were the causes that determined the change in dynamics of the livestock sector in those regions.

Meanwhile, the permanent backwardness of the livestock sector in the NE region during the study was due to lower growth of most of their activities than the national average; coupled with a constant specialization in beef, this activity has slow growth in the country. In this regard, some authors $(5,6,7)$ reported the dynamics and regional growth of pig production in Mexico, which has a similar pattern in some regions and different in others because different periods were evaluated.

The presence of regional specialization, contributed to the growth of the livestock sector in those territories that had positive structural and modified structural effects.

End of english version 


\section{CRECIMIENTO Y ESPECIALIZACIÓN REGIONAL DEL SECTOR PECUARIO EN MEXICO}

último, el crecimiento del sector pecuario regional superó al nacional.

El crecimiento del pollo, huevo y carne de cerdo, así como la especialización regional en los dos primeros productos, fueron las causas que determinaron el cambio de dinamismo del sector pecuario en esas regiones.

Por su parte, el rezago permanente del sector pecuario en la región NE durante el estudio, fue porque el crecimiento de la mayoría de sus actividades fue inferior al nacional; aunado a una constante especialización en carne de bovino, cuya actividad fue de lento crecimiento en el país. Al respecto, grupos de investigadores $(5,6,7)$, reportaron la dinámica y crecimiento regional de la producción porcina en México, que es un comportamiento similar en algunas regiones y diverso en otras, debido a que se evaluaron periodos distintos.

La presencia de especialización regional, contribuyó al crecimiento del sector pecuario en aquellos territorios cuyos efectos estructurales y estructurales modificados fueron positivos.

\section{LITERATURA CITADA}

1. Escalante SRI, Catalán H. Situación actual del sector agropecuario en México: perspectivas y retos. Economía informa 2008;(350):7-25.

2. Basurto HS, Escalante SR. Impacto de la crisis en el sector agropecuario en México. Economíaunam 2012;9(25):51-73.

3. Brambila PJJ, Martínez DMA, Rojas RMM, Pérez CV. El valor de la producción agrícola y pecuaria en México: fuentes del crecimiento, 1980-2010. Rev Mex Cienc Agríc 2014;5(4):619631.

4. SAGARPA. Secretaría de Agricultura, Ganadería, Desarrollo Rural, Pesca y Alimentación. Situación actual y perspectiva de la producción de carne de pollo en México 2009. www.sagarpa.gob.mx/ganaderia/Publicaciones/Lists/ Estudios\%20de\%20situacin\%20actual\%20y\%20perspectiva/ Attachments/28/sitpollo09.pdf. Consultado 9 feb, 2015.

5. Rebollar RA, Gómez TG, Rebollar RS, Hernández MJ, González RFD. Dinámica regional de la producción porcina en México, 1994-2012. Agrociencia 2015;(49):455-473.
6. Bobadilla SEE, Espinoza OA, Martínez CFE. Dinámica de la producción porcina en México de 1980 a 2008. Rev Mex Cienc Pecu 2010;1(3):251-268.

7. Del moral BLE, Ramírez GBP, Muñoz JAR. Crecimiento regional de la producción de carne de cerdo en México, 1980-2005. Análisis económico 2008;XXIII(52):271-290.

8. Bassols BA. Geografía económica de México: teoría, fenómenos generales, análisis regional. 4ta ed. México, D.F: Trillas; 1980.

9. Ruiz FM. Evolución reciente y perspectivas del sector agropecuario en México. ICE 2005;(821):89-106.

10. Boisier S. Técnicas de análisis regional con información limitada. Santiago de Chile: Cuadernos del Instituto Latinoamericano y del Caribe de Planificación Económica y Social (ILPES). Serie II, número 27; 1980.

11. Cuadrado RJR, Mancha NT, Garrido YR. Convergencia regional en España: hechos, tendencias y perspectivas. Fundación Argentaria España: Visor; 1998.

12. Lira L, Quiroga B. Técnicas de análisis regional. Santiago de Chile: Manuales del Instituto Latinoamericano y del Caribe de Planificación Económica y Social (ILPES). 2003(30).

13. SIAP. Servicio de Información Agroalimentaria y Pesquera. Información de mercados. http://www.siap. gob.mx/ ?option=com_content\&view=article\&id= $181 \&$ Itemid $=426$. Consultado 9 ene, 2015.

14. Rendón RL, Mejía RP, Salgado VMC. Especialización y crecimiento manufacturero en dos regiones del Estado de México: un análisis comparativo. Economía: teoría y práctica 2013;(38):111-148.

15. Financiera Rural. Monografía de carne de bovino 2012. www. financierarural.gob.mx/informacionsectorrural/ Documents/Monografias/Monograf\%EDaCarneBovino (feb2012).pdf. Consultado 12 feb, 2015.

16. Ruiz GJL, Aguilar VA, Gómez GG, Ruiz LJ. Circuitos de gestión del conocimiento: innovación para la competitividad de la agroindustria lechera en la región lagunera (CoahuilaDurango, México). Rev Mex Agronegocios 2005;IX(17):118.

17. Odermatt $\mathrm{P}$, Santiago $\mathrm{CMJ}$. Ventajas comparativas en la producción de leche en México. Comercio Exterior 1997:955961.

18. Sierra MLD, Ortiz RB, Sierra VAC, Rivera LJA, Sanginés GJR, Magaña MMA. Estructura del mercado y comportamiento del precio de la carne de cerdo en Yucatán. Téc Pecu Méx 2005;43(3):347-360.

19. Bobadilla SEE, Franco MS, Regil GHH, Martínez CFE. Inventario porcino y su evolución en México. En: Bobadilla SEE, Martínez CFE editores. Porcicultura mexicana: auge y crisis de un sector. México: Universidad Autónoma Chapingo; 2013:33-51.

20. Nava NJJ, Trueta SR, Finck VB, Barranco VB, Osorio HE, Lecumberri LJ. Impactos del nivel tecnológico en la eficiencia productiva y variables económicas, en granjas porcinas de Guanajuato, Jalisco, Sonora y Yucatán. Téc Pecu Méx 2009;47(2):157-172.

21. ASERCA. Agencia de Servicios a la Comercialización y Desarrollo de Mercados Agropecuarios. Huevo. Claridades Agropecuarias 1996;(36):1-44. 